\title{
Noradrenergic Neurons from the Locus Ceruleus in Dissociated Cell Culture: Culture Methods, Morphology, and Electrophysiology
}

\author{
S. Masuko, ${ }^{1}$ Y. Nakajima, S. Nakajima, and K. Yamaguchi ${ }^{2}$ \\ Department of Biological Sciences, Purdue University, West Lafayette, Indiana 47907
}

\begin{abstract}
We have developed a dissociated primary cell culture of noradrenergic neurons from the locus ceruleus of postnatal (1- to 5-d-old) mice or rats. Slices of the brain stem were made on a Vibratome. Then the region of locus ceruleus, which was identified by observing the slices under a dissecting microscope, was dissected out from the slices. The removed fragments of brain slices were dissociated and cultured up to 3 weeks on a nonneuronal feeder layer, which consisted predominantly of astroglial cells, or on a fibronectin-treated collagen substratum. After 2 weeks of culture, about $70 \%$ of total neuronlike cells revealed positive catecholamine histofluorescence, indicating that they were probably noradrenergic neurons. Abont $98 \%$ of large- and medium-sized cultured neurons (soma diameter $\geq 20 \mu \mathrm{m}$ ) was histofluorescence positive. The fluorescence-positive cells had long processes rich in varicosities, and the shape of their soma was either multipolar or fusiform. Electron microscopy using permanganate fixation revealed that the varicosities along their processes had small granular vesicles, which may contain norepinephrine. Physiological properties of these noradrenergic neurons were investigated with intracellular microelectrodes or with the whole-cell version of the patch clamp. We observed that many cells were producing spontaneous firing. Many of these spontaneously firing cells had no obvious contact with neighboring cells. The neurons were depolarized when glutamate was applied by pressure ejection. They also responded to GABA and glycine with either hyperpolarization or depolarization, and these responses were antagonized by picrotoxin and strychnine. Application of substance $\mathbf{P}$ generally produced depolarization with an increase in input resistance. The neurons responded with hyperpolarization to somatostatin, $\beta$-endorphin, and enkephalin. This culture system will become a useful tool for elucidating the cellular and molecular properties of the central noradrenergic neurons.
\end{abstract}

The locus ceruleus, a pair of nuclei located in the pons, is an assembly of tightly packed noradrenergic neurons (Amaral and Sinnamon, 1977; Dahlström and Fuxe, 1964; Foote et al., 1983; Swanson and Hartman, 1975). The neurons innervate very wide areas of the brain and spinal cord (Andén et al., 1966; Olson and Fuxe, 1971; Ungerstedt, 1971) and are implicated in diverse physiological functions such as maintenance of arousal state or mediation of stress responses. Electrophysiological and phar-

\footnotetext{
Received Jan. 14, 1986; revised Apr. 4, 1986; accepted Apr. 17, 1986.

We are grateful to Dr. Peter $R$. Stanfield for critically reading the manuscript. Thanks are also due to Ms. Sara E. Huestis and Ms. Pamella A. Schroeder for their technical assistance. This work was supported by National Institutes of Health Grant AG06093.

Correspondence should be addressed to Dr. Yasuko Nakajima at the above address.

IPresent address: Department of Anatomy, Saga Medical School, Nabeshima, Saga 840-01, Japan.

${ }^{2}$ Present address: National Institute for Physiological Sciences, Myodaiji, Okazaki 444, Japan.

Copyright (c) 1986 Society for Neuroscience $0270-6474 / 86 / 113229-13 \$ 02.00 / 0$
}

macological properties of these noradrenergic neurons have been extensively investigated in in situ preparations or in brain slices (Aghajanian and VanderMaelen, 1982; Aghajanian et al., 1983; Chu and Bloom, 1973; Henderson et al., 1982; Nakamura and Iwama, 1975; Olpe and Jones, 1982; Svensson et al., 1975; Williams et al., 1982, 1984). These studies have shown that the neurons produce spikes continuously, and the spike frequency changes in response to various neurotransmitters or neuromodulators, suggesting that the neurons are rich in various kinds of neuroreceptors.

It is very desirable to develop a cell culture system of the locus ceruleus. It would facilitate the investigation of various properties of these noradrenergic neurons under well-controlled conditions. It would also allow us to study precise mechanisms of the neuronal membrane by the use of the patch-clamp technique (Hamill et al., 1981). Thus far, there have been no reports of successful dissociated cell culture of these noradrenergic neurons, although the techniques of organotypic cultures have been described (Dreyfus et al., 1979, 1983; Hendelman et al., 1982; Olson et al., 1979; Schlumpf et al., 1977; Victorov et al., 1978).

The primary purpose of our investigation reported here was to develop a method of making a dissociated cell culture of the locus ceruleus which is functionally alive and can be used for electrophysiological investigations. In this paper we will give a detailed account of our technique of culturing. Also we will describe the structure of cultured neurons at the light-microscopic and electron-microscopic levels. Electrophysiological responses and some pharmacological properties will also be described. A preliminary account of this work has already appeared (Masuko et al., 1984).

\section{Materials and Methods}

\section{Cell culture}

The salient features of our method are to make thin brain slices of the pons using a Vibratome, then to remove the locus ceruleus region under direct visualization through a dissecting microscope, and to make a dissociated culture inside a very small culture chamber.

Newborn mice (1-5 d old; $\left.B 6 \mathrm{D} 2 \mathrm{~F}_{1}\right)$ were used. In a few experiments, newborn Wistar rats were also used. The brain was removed aseptically under ether anesthesia and quickly immersed in an oxygenated ice-cold balanced salt solution consisting of $\mathrm{NaCl}, 130 \mathrm{~mm} ; \mathrm{KCl}, 4.5 \mathrm{~mm} ; \mathrm{CaCl}_{2}$, $2 \mathrm{~mm}$; glucose, $33 \mathrm{~mm}$; and PIPES buffer, $5 \mathrm{~mm}$ (pH 7.4). The brain stem was isolated together with the cerebellum and embedded in $2.5 \%$ agar in the balanced salt solution. The agar block was then hardened by cooling (Takahashi, 1978) and was adhered to a sterilized disposable square petri dish $(10 \times 10 \times 1.5 \mathrm{~cm})$ with Aron Alpha glue (Alpha cyanoacrylate). The petri dish was mounted on a Vibratome (Lancer 1000 ), and transverse brain slices, $200-300 \mu \mathrm{m}$ in thickness, were sectioned in the oxygenated balanced salt solution. These brain slices were examined under a dissecting microscope, and tissue fragments from the region of locus ceruleus were cut out by using a pair of hypodermic needles.

The tissue fragments were incubated in $0.25 \%$ trypsin (Gibco) in a calcium-free balanced salt solution for $30 \mathrm{~min}$ at room temperature (or 

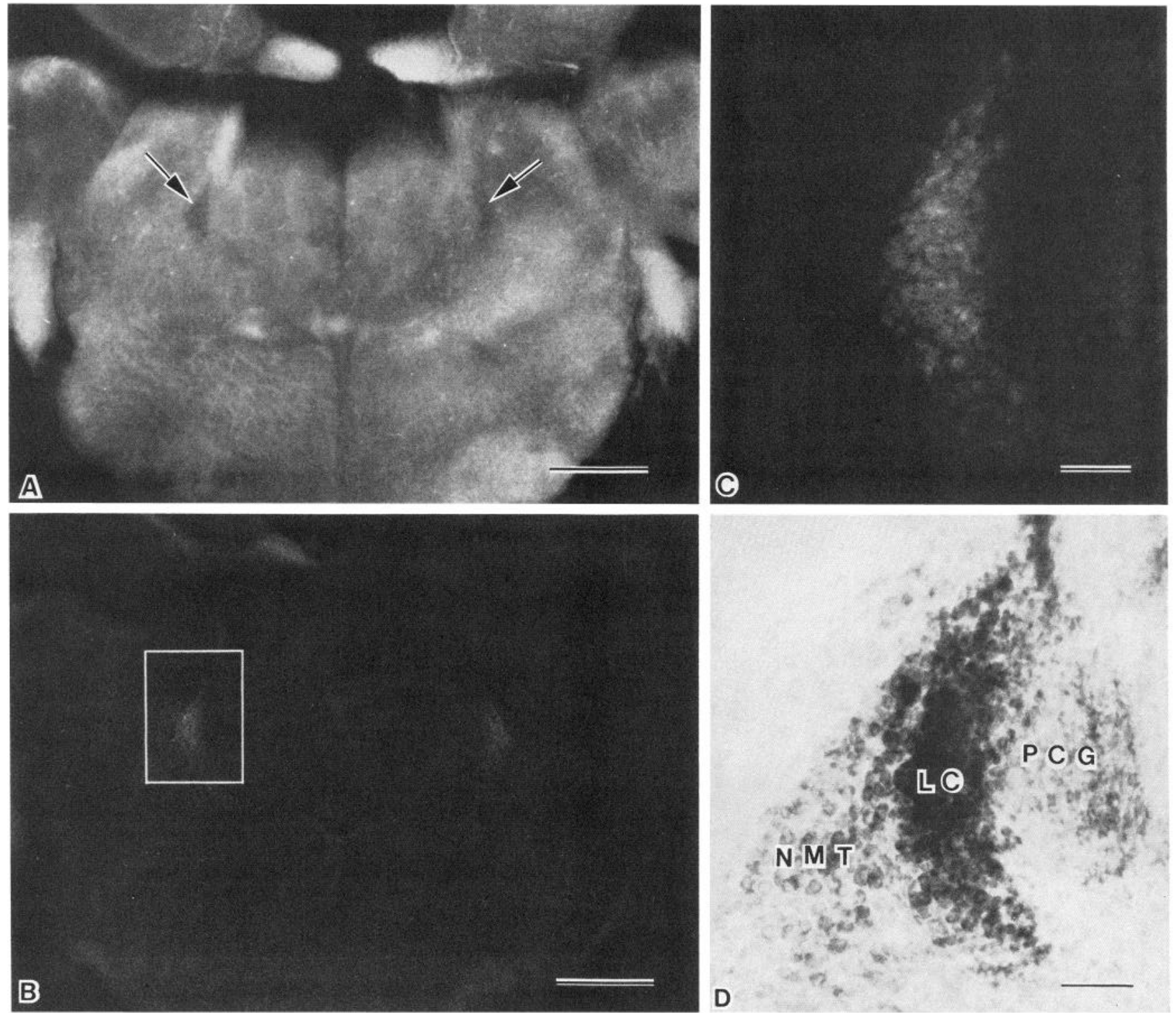

Figure 1. Transverse slice (100 $\mu \mathrm{m}$ thick) of the pons of a newborn mouse sectioned on a Vibratome. $A$, Fresh, unfixed slice observed with a dissecting microscope. The locus ceruleus (arrows) is seen as a somewhat translucent, crescent-shaped region. Bar, $500 \mu \mathrm{m}$. $B$, Same slice as in $A$ treated with glyoxylic acid reveals catecholamine histofluorescence in the locus ceruleus region. Bar, $500 \mu \mathrm{m}$. $C$, High-magnification picture of $B$ showing fluorescence-positive cells. Bar, $100 \mu \mathrm{m}$. $D$, Same slice stained with toluidine blue. Tightly packed locus ceruleus neurons $(L C)$ are seen between the nucleus of the mesencephalic tract of the trigeminal nerve $(N M T)$ and the pontine central gray $(P C G)$. Bar, $100 \mu \mathrm{m}$.

for $15 \mathrm{~min}$ at $37^{\circ} \mathrm{C}$ ) and were dissociated in a culture medium (see below) by trituration with a Pasteur pipette with a narrow, heat-polished tip. (Pure mechanical dissociation without trypsin treatment was sometimes employed, resulting in cultures of similar character.) The culture medium was a modified Eagle's minimum essential medium (with Earle's salt) containing the following: L-glutamine, $2.92 \times 10^{-4} \mathrm{gm} / \mathrm{ml}$; glucose, $6 \times 10^{-3} \mathrm{gm} / \mathrm{ml} ; \mathrm{NaHCO}_{3}, 3.7 \times 10^{-3} \mathrm{gm} / \mathrm{ml} ; \mathrm{L}$-ascorbic acid, $1 \times$ $10^{-5} \mathrm{gm} / \mathrm{ml}$; penicillin, 50 units $/ \mathrm{ml}$; streptomycin, $50 \mu \mathrm{g} / \mathrm{ml} ; 10 \%$ fetal bovine serum; and $10 \%$ heat-inactivated horse serum. The culture chamber was a petri dish with a 1.2-cm-diameter well at the center (O'Lague et al., 1978). The bottom of the well was made of a carboncoated coverglass or an Aclar fluorohalocarbon film $12.7 \mu \mathrm{m}$ in thickness (Allied Fibers and Plastics, Morristown, NJ). The dissociated cell suspension was plated inside this well at a density of about $5 \times 10^{3}$ cells/ $\mathrm{cm}^{2}$.

Prior to the culturing, the coverglass (or the Aclar film) constituting the bottom of the well was coated with collagen and then treated with $25 \mu \mathrm{g} / \mathrm{ml}$ human fibronectin (Sigma) (Yamamoto et al., 1981), or coated with collagen and a feeder layer. The feeder layer consisted of cultured non-neuronal cells, predominantly astroglial cells, obtained from brain stems of newborn mice. The feeder layer was prepared as follows. The brain stems were sliced on a Vibratome, and as much of the connective tissue covering the brain stem was removed as possible. After treatment with $0.25 \%$ trypsin, these brain slices were dissociated and cultured. During the first 4-5 weeks of culturing, the brain stem cultures were replated once a week. With this procedure neuronal cells were usually eliminated, and non-neuronal cells, mostly glial cells, survived. These non-neuronal cells were used for making feeder layers. In order to suppress mitosis, the feeder layers were treated with 5 '-fluoro-2'-deoxyuridine and uridine (final concentration, 15 and $35 \mu \mathrm{g} / \mathrm{ml}$, respectively) for $24 \mathrm{hr}$ just before neurons from the locus ceruleus were plated.

All the culture procedures, including sectioning on the Vibratome, were performed inside a laminar flow hood under aseptic conditions. The cultures were kept at $37^{\circ} \mathrm{C}$ in an atmosphere of $10 \% \mathrm{CO}_{2}, 90 \%$ air at a saturated level of humidity for 2-4 weeks. The culture media were changed at 3-7 d intervals. 

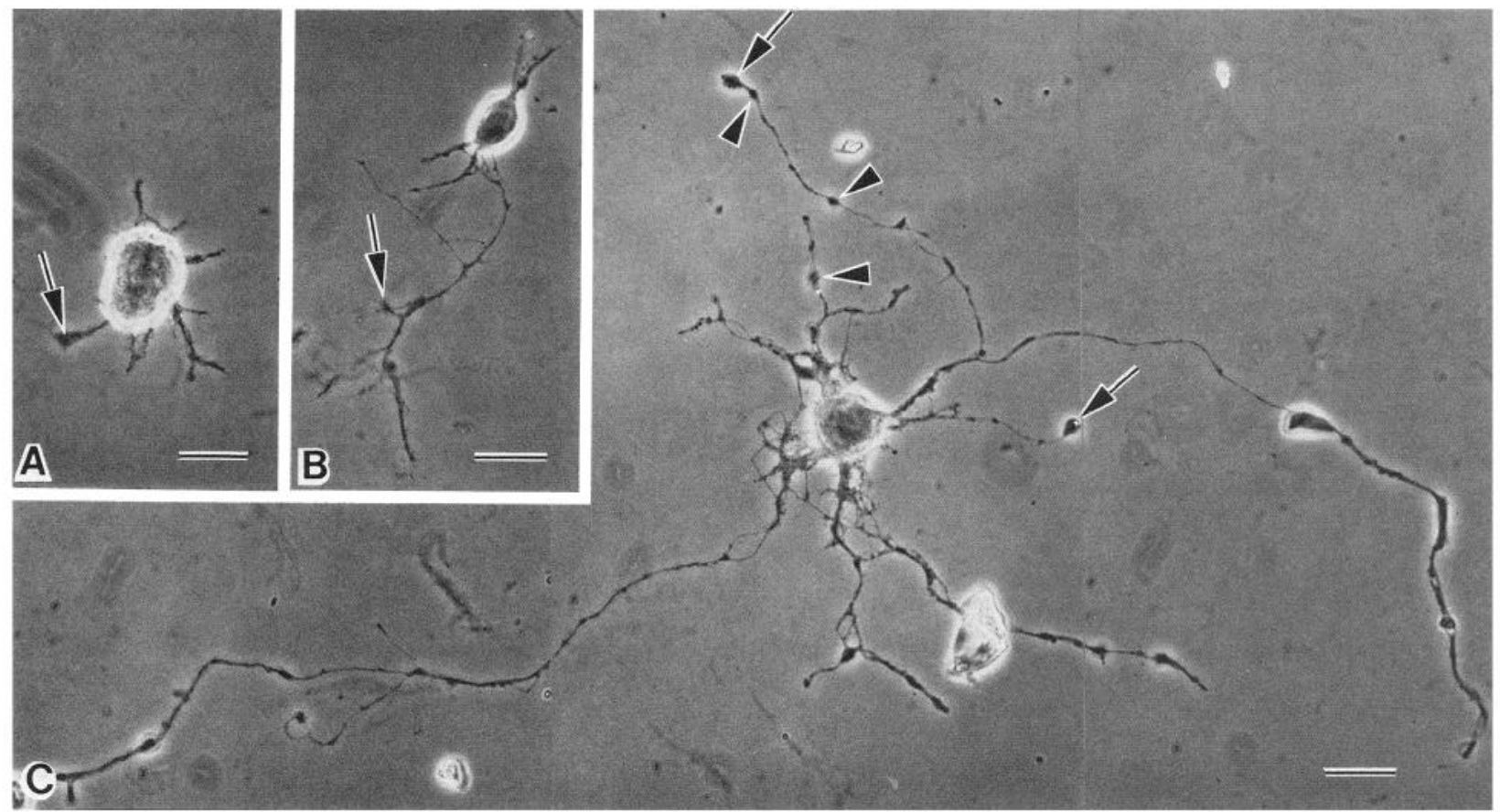

Figure 2. Phase-contrast micrographs of dissociated cultured neurons from the locus ceruleus of newborn mice. Neurons were grown on a fibronectin-treated collagen layer. $A$ and $B$, Twenty-four hour cultured neurons having short neuronal processes. Arrows indicate flattened growth cones. $C$, A $7 \mathrm{~d}$ cultured neuron. Note well-developed processes, varicosities (arrowheads), and boutonlike growth cones (arrows) seen at the tips of the processes. Bars, $20 \mu \mathrm{m}$.

\section{Fluorescence histochemistry}

For fluorescence histochemistry of catecholamines, we used the procedure described by Prochiantz et al. (1979). The preparation was preincubated in a culture medium with added $0.1 \mathrm{~mm}$ paragyline for $30-60$ $\mathrm{min}$ at $37^{\circ} \mathrm{C}$ and was then fixed for $15 \mathrm{~min}$ in an ice-cold phosphatebuffered Krebs-Ringer solution $\left(\mathrm{CaCl}_{2}\right.$ replaced by $\left.\mathrm{MgCl}_{2}, \mathrm{pH} 7.0\right)$ containing $2 \%$ glyoxylic acid and $0.5 \%$ paraformaldehyde. After fixation it was dried in a warm airstream and heated in an oven at $90^{\circ} \mathrm{C}$ for $15-$ $20 \mathrm{~min}$. The cultures were then mounted in liquid paraffin and examined with a Zeiss epi-illumination fluorescence microscope equipped with BP 405/8 excitation and LP 450 barrier filters.

\section{Electron microscopy}

The cultures were fixed with $2.5 \%$ glutaraldehyde in $0.12 \mathrm{M}$ phosphate buffer ( $\mathrm{pH} 7.4$ ) for $1 \mathrm{hr}$ at room temperature and then postfixed with $1 \%$ osmium tetroxide in the same buffer. After fixation the cultures were block-stained with $1 \%$ uranyl acetate in $50 \mathrm{~mm}$ acetate buffer $(\mathrm{pH} \mathrm{5.2)}$, dehydrated, and embedded in Epon. For the purpose of demonstrating norepinephrine-containing synaptic vesicles, the cultures were fixed with ice-cold 3\% potassium permanganate in a phosphate-buffered Krebs solution ( $\mathrm{pH} \mathrm{7.0)}$ for 30-45 min (Hökfelt, 1967). Thin sections were cut parallel to the culture substratum and examined with a Philips 300 EM.

\section{Electrophysiology}

We followed the method described in O'Lague et al. (1978) for electrophysiological experiments. The petri dish, with cultured cells inside the center well, was placed inside a metal collar containing a Nichrome heating unit. A stainless steel block with a center hole was fitted snugly inside the petri dish, and the superfusion of the bathing solution was started. The stainless steel block served to limit the volume of the solution in the bath and to facilitate the conduction of heat from the heating unit into the center well (see O'Lague et al., 1978, for details).

For intracellular recording, the microelectrode was filled with $2 \mathrm{M}$ $\mathrm{K}$-acetate (or sometimes with $2 \mathrm{M} \mathrm{K}$-methylsulfate) and had a resistance of 100-200 M . An active bridge circuit was used to apply currents through the recording electrode (Bridgman et al., 1984). During the experiment the culture was constantly superfused with a Krebs solution $\left(\mathrm{NaCl}, 126 \mathrm{~mm} ; \mathrm{KCl}, 2.5 \mathrm{~mm} ; \mathrm{CaCl}_{2}, 2.4 \mathrm{~mm} ; \mathrm{NaH}_{2} \mathrm{PO}_{4}, 1.6 \mathrm{~mm} ; \mathrm{MgCl}_{2}\right.$, $1.3 \mathrm{~mm}$; $\mathrm{NaHCO}_{3}, 25 \mathrm{~mm}$; and glucose, $11 \mathrm{~mm}$ ), equilibrated with $\mathrm{O}_{2}$ (95\%) and $\mathrm{CO}_{2}(5 \%)$.

The whole-cell version of the patch-clamp technique was used (Hamill et al., 1981). The patch pipette was filled with the following solution: $\mathrm{K}$-aspartate, 110 (or 95) $\mathrm{mm}$; $\mathrm{NaCl}$ (or $\mathrm{KCl}$ ), $40 \mathrm{~mm}$; HEPES-KOH buffer, 5 (or 10) mM; EGTA-KOH, 5 mM; $\mathrm{MgCl}_{2}, 3 \mathrm{~mm}$; and $\mathrm{Na}_{2}$ ATP, $2 \mathrm{~mm}$ (pH 6.7-7.4). The external solution was an oxygenated Krebs solution with a HEPES buffer $\left(\mathrm{NaCl}, 148 \mathrm{~mm} ; \mathrm{KCl}, 2.5 \mathrm{~mm} ; \mathrm{CaCl}_{2}, 2.4\right.$ $\mathrm{mM} ; \mathrm{MgCl}_{2}, 1.3 \mathrm{~mm}$; HEPES-NaOH buffer, $5 \mathrm{~mm}$; and glucose, $11 \mathrm{~mm}$ ). The value of resting potential was corrected for the liquid junction potential $(9 \mathrm{mV})$ between the patch pipette and external solution. Drugs were applied by pressure ejection from a micropipette with a tip diameter of 2-6 $\mu \mathrm{m}$ (Choi and Fischbach, 1981). The temperature near the cell, measured with a fine-tip thermocouple, was $28-36^{\circ} \mathrm{C}$ (mean, $\left.32^{\circ} \mathrm{C}\right)$.

\section{Results}

\section{Isolation of the locus ceruleus}

In order to make the cell culture of the locus ceruleus, it was necessary to locate the locus ceruleus in brain slices accurately. For this purpose, we first observed freshly sectioned brain slices under the dissecting microscope (Fig. $1 A$ ). The slices were then treated for catecholamine histofluorescence (Fig. 1, $B, C$ ) and further stained with toluidine blue (Fig. $1 D$ ). As seen in Figure $1, B-D$, the locus ceruleus of newborn mice consisted of densely packed neurons which revealed catecholamine histofluorescence, in agreement with observations of newborn rats (Lauder and Bloom, 1975; Sievers and Lolova, 1981). Figure $1 A$, in comparison with Figure $1, B$ and $C$, indicates that in unstained slices the locus ceruleus can be identified as a translucent, granular, crescent-shaped region beneath the lateral edge of the fourth ventricle; this is the same location as described in the adult mouse (Lauder and Bloom, 1975; Sievers and Lolova, 1981). 

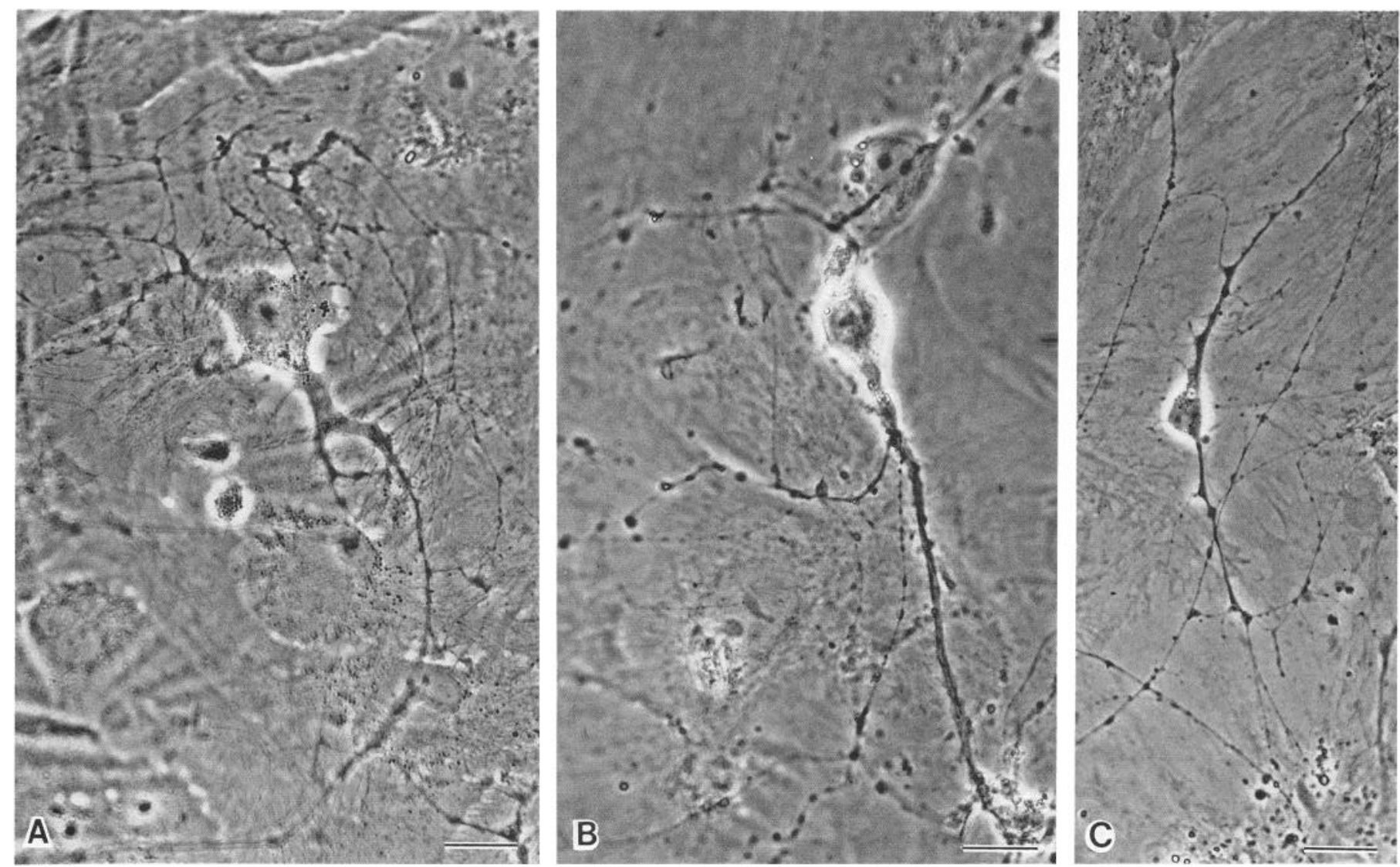

Figure 3. Phase-contrast micrographs of isolated locus ceruleus neurons grown on a feeder layer for $14 \mathrm{~d}$. $A$, Large multipolar cell. $B$, Mediumsized fusiform cell. $C$, Small fusiform cell. Bars, $20 \mu \mathrm{m}$.

These landmarks enabled us to isolate the locus ceruleus from brain slices under the dissecting microscope.

\section{Culture}

Over $95 \%$ of the cells dissociated from the locus ceruleus excluded trypan blue, a vital dye for viability tests, and the total cell yield was about $5 \times 10^{3}$ per mouse. Figure 2 shows cultured cells grown on fibronectin-treated collagen substratum. The dissociated cells settled down on the substratum and started to extend processes within $24 \mathrm{hr}$ (Fig. 2, $A, B$ ). Flattened growth cones were visible at the tips of some of these processes. During the subsequent days in culture, the processes increased in length and number. After $7 \mathrm{~d}$ of culture, many cells showed a multipolar configuration with several long and many short processes. There were many varicosities along these processes (Fig. 2C). By this time, growth cones became rounder and showed a boutonlike appearance (Fig. 2C). Neuronal survival under these culture conditions was good during the first $10 \mathrm{~d}$ of incubation, but the cells often started to deteriorate thereafter. (We assumed that cells with characteristic neuronal appearance, such as long processes and growth cones, were neuronal cells.)

When cultured on the glial feeder layer, neurons tended to survive longer. Figure 3 shows examples of neuronal cells grown on the feeder layer. The neurons could be classified into 2 major classes: multipolar and fusiform. Figure $3 A$ shows a multipolar neuron: This is a cell with a multipolar-shaped soma from which several major neurites emerge. Figure $3 B$ illustrates a mediumsized fusiform cell: The soma has a spindle form with major neurites arising from opposite poles of the soma. Figure $3 C$ shows a small fusiform cell.

\section{Catecholamine histofluorescence}

Glyoxylic acid histochemistry revealed the presence of many cells with intense histofluorescence (Fig. 4). As shown in Figure $4 A, 24 \mathrm{hr}$ cultured neurons exhibited strong fluorescence in their soma but not in their neurites. After 2 weeks of culture, however, both perikaryon and processes, particularly at the sites of varicosities, showed intense fluorescence (Fig. 4, $B, C$ ). Figure $4 D$ shows a cell that fluoresces little and is indistinguishable from the background level. Almost all these fluorescence-negative cells were small and fusiform.

Table 1 summarizes the frequency of fluorescence-positive cells cultured for 2 weeks. Nearly $70 \%$ of total neuronlike cells exhibited histofluorescence, and these cells were larger (average soma diameter, $22.4 \mu \mathrm{m}$ ) than fluorescence-negative cells (average, $10.4 \mu \mathrm{m}$ ). If we take only large cells (diameter $\geq 20 \mu \mathrm{m}$ ), almost all (98\%) were catecholamine fluorescence-positive (not shown in Table 1). As shown in Table 2, among fluorescencepositive neurons multipolar cells predominate (77\%), and their size is larger (diameter, $24.7 \mu \mathrm{m}$ ) than that of fusiform cells (diameter, $14.6 \mu \mathrm{m}$ ).

By and large, the morphological characteristics of our cultured cells, as described above, resemble those of locus ceruleus neurons from the in vivo rat brain reported by Swanson (1976). The catecholamine histofluorescence in our culture is most probably derived from norepinephrine, since there are no reports concerning the existence of neurons containing other monoamines near the brain region, from which the tissue was acquired. We conclude that the fluorescence-positive cells in our culture are 

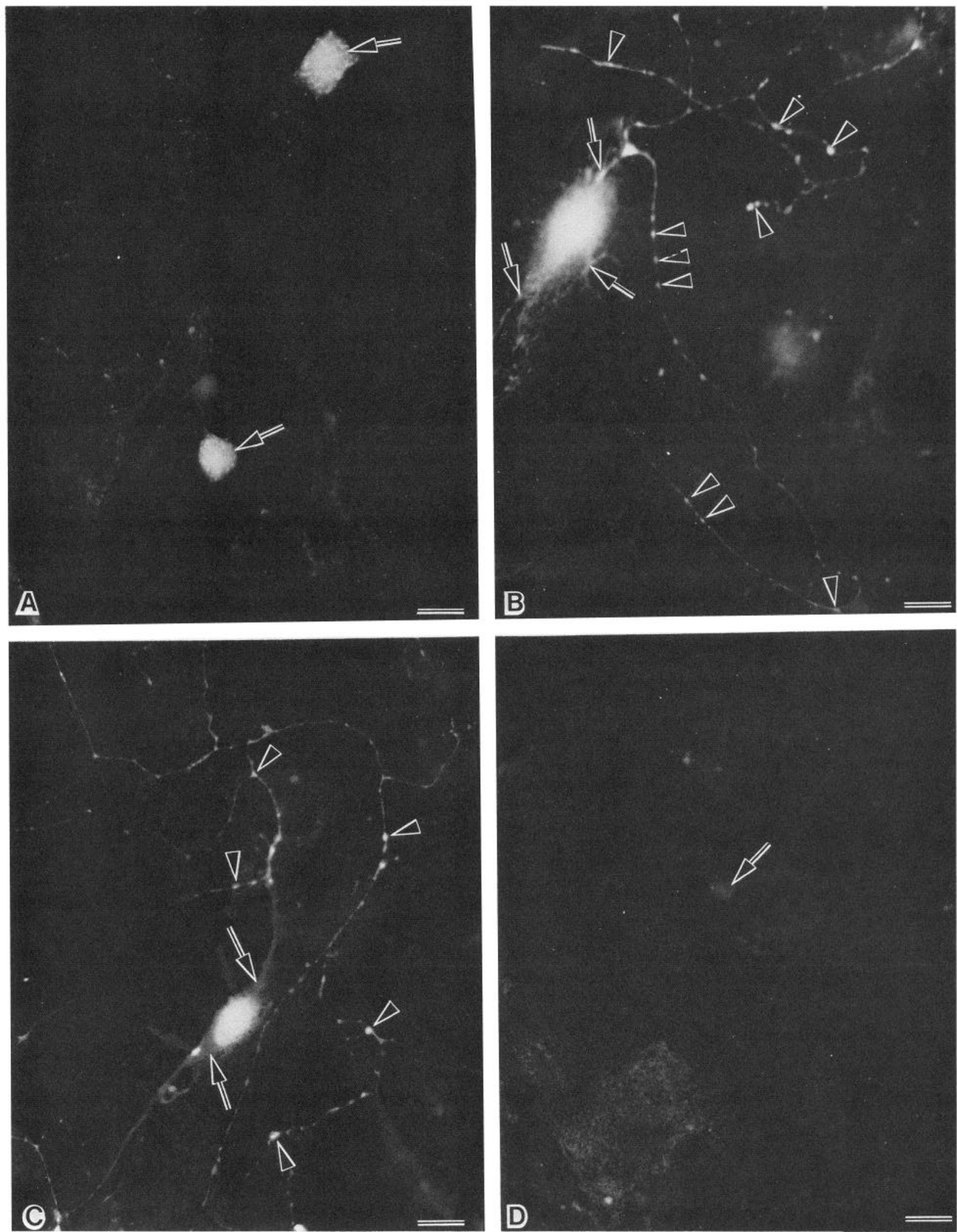

Figure 4. Fluorescence micrographs of cultured neurons from the locus ceruleus of newborn mice. Neurons were grown on a feeder layer and treated with glyoxylic acid for catecholamine histofluorescence. $A$, Twenty-four hour cultured large and medium-sized neurons (arrows) possessing intense fluorescence at their cell bodies. $B-D$, Fourteen day cultured neurons. $B$, Large multipolar neuron possessing catecholamine histofluorescence in the cell body and in the neuronal processes, particularly in varicose regions (arrowheads). Arrows indicate the initial parts of major neurites. $C$, Medium-sized fusiform neuron possessing catecholamine histofluorescence in the cell body and in neuronal processes, particularly in varicosities (arrowheads). Arrows indicate the initial parts of 2 major neurites. D, Small neuron (arrow) showing only the background level of fluorescence. Bars, $20 \mu \mathrm{m}$ 


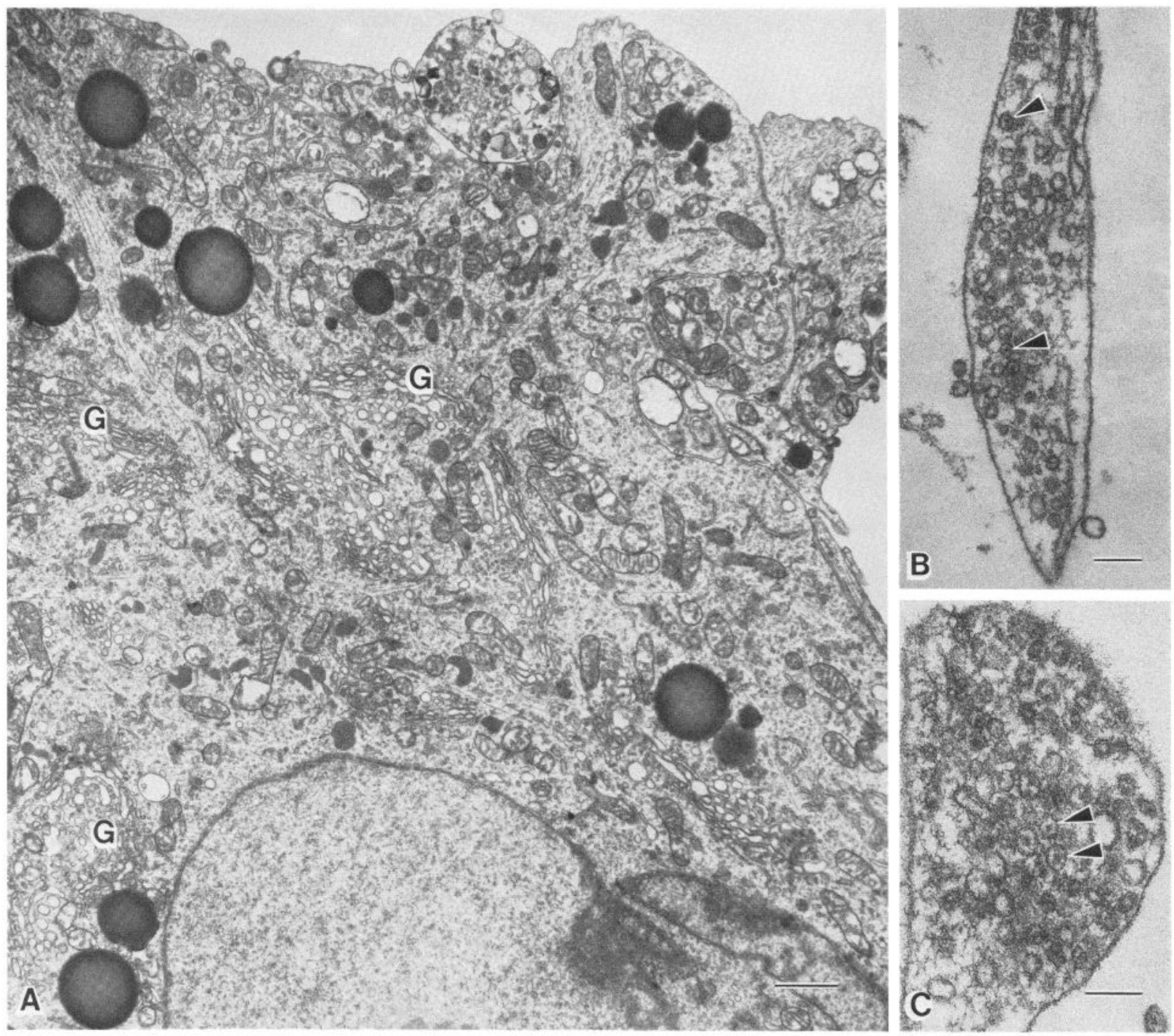

Figure 5. Electron micrographs of $15 \mathrm{~d}$ cultured neurons from the locus ceruleus of newborn mice. A, Glutaraldehyde- and osmium tetroxidefixed material. Cell body region of the neuron showing the presence of many mitochondria, Golgi complexes $(G)$, and many large electron-dense bodies. Bar, $1 \mu \mathrm{m} . B$ and $C$, Potassium permanganate-fixed material. Varicosities along neuronal processes contain small granular vesicles (arrowheads). These may represent synaptic vesicles containing norepinephrine (Hökfelt, 1967). Bars, $0.1 \mu \mathrm{m}$.

most probably noradrenergic neurons derived from the locus ceruleus.

\section{Electron microscopy}

Specimens cultured for 2 weeks were examined with an EM. Figure $5 A$ shows a part of the perikaryon of a multipolar neuron fixed with glutaraldehyde. The cytoplasm of the neuron contains many mitochondria, well-developed Golgi complexes, and nu-

Table 1. Catecholamine histofluorescence of cultured neurons

\begin{tabular}{lllll}
$\begin{array}{l}\text { Histo- } \\
\text { fluores- } \\
\text { cence }\end{array}$ & $\begin{array}{l}\text { Fre- } \\
\text { quency } \\
(\%)\end{array}$ & $\begin{array}{l}\text { Major } \\
\text { diameter } \\
(\mu \mathrm{m})\end{array}$ & $\begin{array}{l}\text { Minor } \\
\text { diameter } \\
(\mu \mathrm{m})\end{array}$ & $\begin{array}{l}\text { Diameter } \\
(\mu \mathrm{m})\end{array}$ \\
\hline$(+)$ & 69 & $25.8 \pm 6.6$ & $19.7 \pm 5.2$ & $22.4 \pm 5.3$ \\
$(-)$ & 31 & $12.3 \pm 3.1$ & $8.9 \pm 3.0$ & $10.4 \pm 2.9$
\end{tabular}

All values presented are means \pm SD. Measurements were conducted on 121 neuronlike cells from 2 cultures. Cells were grown for 2 weeks.

${ }^{a}$ Diameter was defined as a geometrical mean, $(\mathrm{Mm})^{1 / 2}$, of the major $(M)$ and minor $(m)$ soma diameters. merous free ribosomes, which often form small clusters or rosettes. The cytoplasm also contains the granular endoplasmic reticulum. The cisterns of endoplasmic reticulum tend to be dispersed without forming orderly arrays. There are also dense bodies of various sizes (about $0.5-1.0 \mu \mathrm{m}$ ), resembling lysosome granules (Léger and Hernandez-Nicaise, 1980), scattered in the perikaryon (Fig. $5 A$ ). The presence of similar dense bodies has

Table 2. Shape and size of catecholamine histofluorescence-positive cells

\begin{tabular}{lllll} 
Shape & $\begin{array}{l}\text { Fre- } \\
\text { quency } \\
(\%)\end{array}$ & $\begin{array}{l}\text { Major } \\
\text { diameter } \\
(\mu \mathrm{m})\end{array}$ & $\begin{array}{l}\text { Minor } \\
\text { diameter } \\
(\mu \mathrm{m})\end{array}$ & $\begin{array}{l}\text { Diameter } \\
(\mu \mathrm{m})\end{array}$ \\
\hline Multipolar cells & 77 & $28.2 \pm 5.1$ & $21.9 \pm 3.6$ & $24.7 \pm 3.4$ \\
Fusiform cells & 23 & $17.4 \pm 3.6$ & $12.4 \pm 2.1$ & $14.6 \pm 2.3$
\end{tabular}

All values presented are means \pm SD. Measurements were conducted on 84 histofluorescence-positive cells from 2 cultures. Cells were grown for 2 weeks.

${ }^{a}$ Diameter of each was defined as a geometrical mean, $(\mathrm{Mm})^{1 / 2}$, of the major $(M)$ and minor $(m)$ soma diameters. 
A

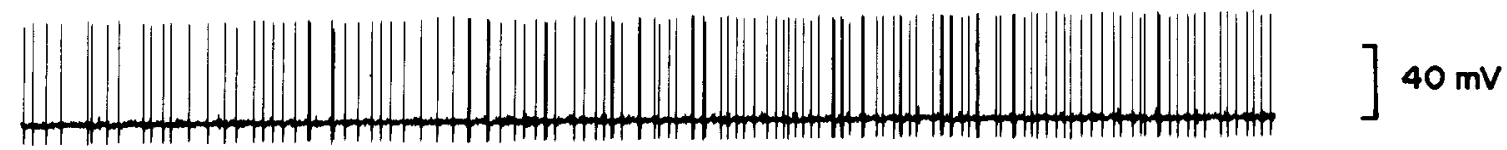

B

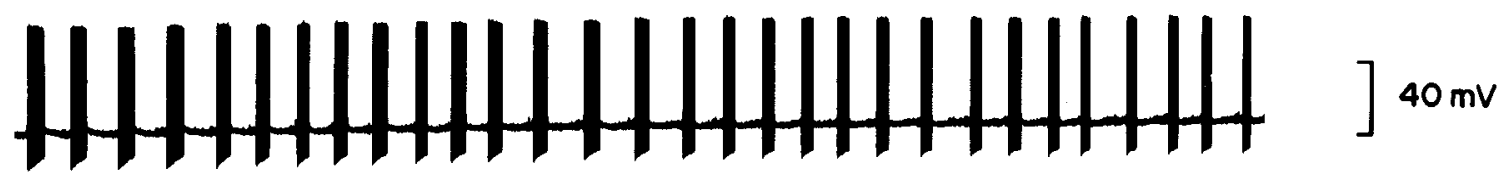

C

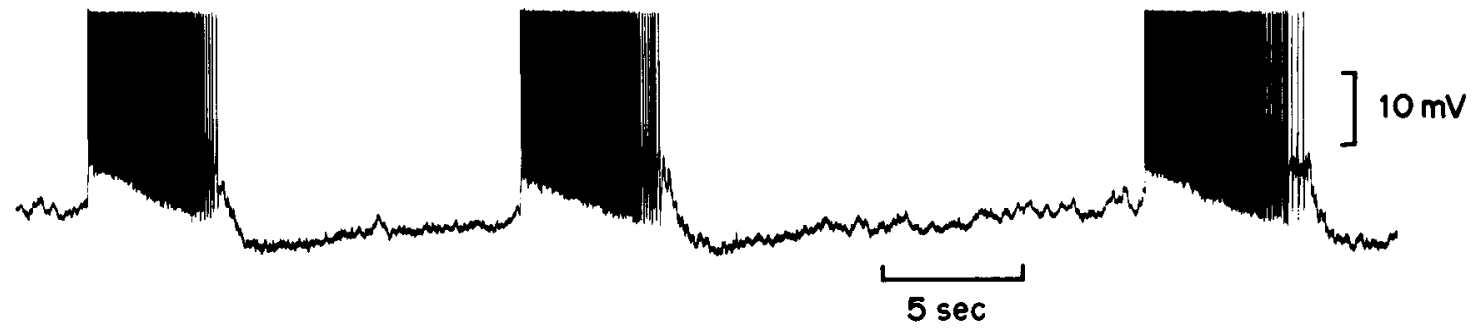

Figure 6. Spontaneous firing recorded from locus ceruleus neurons of 2-4-d-old mice cultured for 12-17 d. A, More or less regular firing pattern. $B$, Bursting behavior with relatively short bursting periods. $C$, Burst with very long periods. Note that a higher amplification was used in this record, resulting in saturation of spike potentials. Data were recorded by intracellular microelectrodes, stored in an FM tape recorder, and played back at slower speeds into a pen recorder. The overall frequency response was $200-320 \mathrm{~Hz}$.

been reported for in situ locus ceruleus neurons (Hendelman et al., 1982; Léger and Hernandez-Nicaise, 1980).

The varicosities of nerve processes contained an accumulation of small granular (or dense-core) vesicles when fixed with permanganate (arrowheads in Fig. 5, B, C). Hökfelt (1967) suggested that these small granular vesicles contain norepinephrine.

\section{Electrophysiology}

All physiological experiments were conducted on neuronal cells cultured on the glial feeder layer. Almost all large neurons $(98 \%$ of cells with $20 \mu \mathrm{m}$ soma diameter or larger) are noradrenergic neurons. Therefore, we attempted to investigate the physiological properties of large neurons. The following physiological data were obtained from 119 neurons: 90 cells of these had a soma diameter of $\geq 20 \mu \mathrm{m}$ (mean, $28.1 \mu \mathrm{m}$ ) and 4 cells were 14-19 $\mu \mathrm{m}$ in diameter; the diameter of the remaining 25 cells was not measured. It is very likely, therefore, that almost all the physiological data were obtained from noradrenergic neurons.

\section{Spontaneous firing}

Intracellular recording revealed that the majority of neurons impaled (71 of 119) were producing spontaneous firing of spike trains (Fig. 6). Most spontaneously firing cells (59 of 71) displayed a more or less regular pattern of firing. The pattern was sometimes disturbed by an "extra firing" interposed or was modified by slow fluctuations occurring apparently at random (Fig. 6A). Some cells (12 of 71) exhibited a "bursting pattern," with a high-frequency period alternating with a quiescent interval (Fig. 6, $B, C$ ). In some cells the bursting period was short (usually $<2 \mathrm{sec}$ ), and there was little hyperpolarization during the quiescent period (Fig. $6 \mathrm{~B}$ ). In other cells, the bursting time was longer (up to $20 \mathrm{sec}$ ) followed by a long quiescent period accompanied by a posttetanic hyperpolarization. (Fig. $6 C$ displays a rare cell in which the bursting period was unusually long and the hyperpolarization prominent.) Spontaneous firing was observed in cclls apparently isolated from any neighboring neurons, as well as in cells that were cultured for only a day and thus lacked long neuronal processes.

As shown in Figure 7, each spike potential was followed by a hyperpolarizing afterpotential lasting about $150 \mathrm{msec}$; there- after, the potential stayed at quasi-steady state, which gradually changed into a slowly creeping depolarizing phase until the spike threshold was reached. These potential changes during interspike periods are very similar to those recorded from the locus ceruleus neurons in intact animals or in brain slices (Aghajanian and VanderMaelen, 1982; Williams et al., 1984).

\section{Passive properties}

Table 3 summarizes the data of passive membrane properties. The resting potential of the cells that are spontaneously firing is defined somewhat arbitrarily as the quasi-steady state potential during the quiescent period. During these quiescent periods, we measured the input resistance and capacity of the neuron by injecting square wave currents through a microelectrode by the bridge circuit (Fig. $8 \mathrm{Al}$ ). In the whole-cell clamp experiments, we measured the passive properties by injecting square wave currents under the current-clamp mode (Fig. $8 B 1$ ). The input capacity $\left(C_{\text {in }}\right)$ was measured by semilogarithmic plotting of the

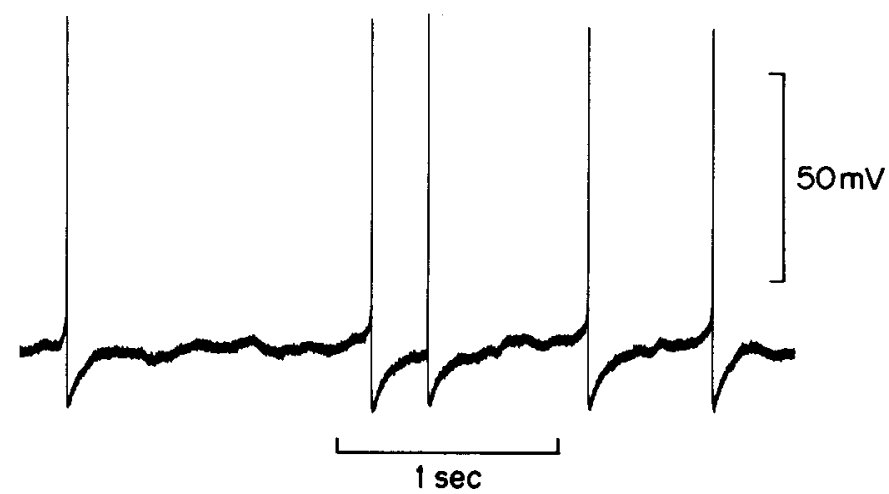

Figure 7. Spontaneous firing showing the time course of hyperpolarizing afterpotentials, recorded from a locus ceruleus neuron of 4-d-old mice cultured for $14 \mathrm{~d}$. The whole-cell clamp was used. Patch pipette contained $\mathrm{K}$-aspartate, $110 \mathrm{~mm} ; \mathrm{NaCl}, 40 \mathrm{~mm}$; etc. (see Materials and Methods). The tape recorder and pen recorder combination was used, with an overall frequency response of $\sim 600 \mathrm{~Hz}$. 
Figure 8. Potential changes produced by hyperpolarizing or depolarizing current steps in cultured locus ceruleus neurons. $A 1$ and $A 2$, Intracellular microelectrode recordings. The locus ceruleus region was taken from a 2-d-old mouse and cultured for $12 \mathrm{~d}$. The upper beams represent voltages; the lower beams, currents. $B 1$ and $B 2$, Whole-cell current clamp recordings. The material was taken from a 4-d-old mouse and cultured for $14 \mathrm{~d}$. The upper beams are currents; lower beams, voltages. C'I-C3, Whole-cell current clamp recordings. The cell, from a 2-d-old mouse, was cultured for $17 \mathrm{~d}$. In $C 2$, TTX, $3 \mu \mathrm{M}$, was superfused. The TTX effect was reversible $(C 3)$. The upper heams are currents; lower beams, voltages. In the whole-cell recording $(B, C)$, small spikes are superimposed on the current traces. They are due to an insufficiency of the current-clamp at high frequency. All records are oscilloscope photographs.
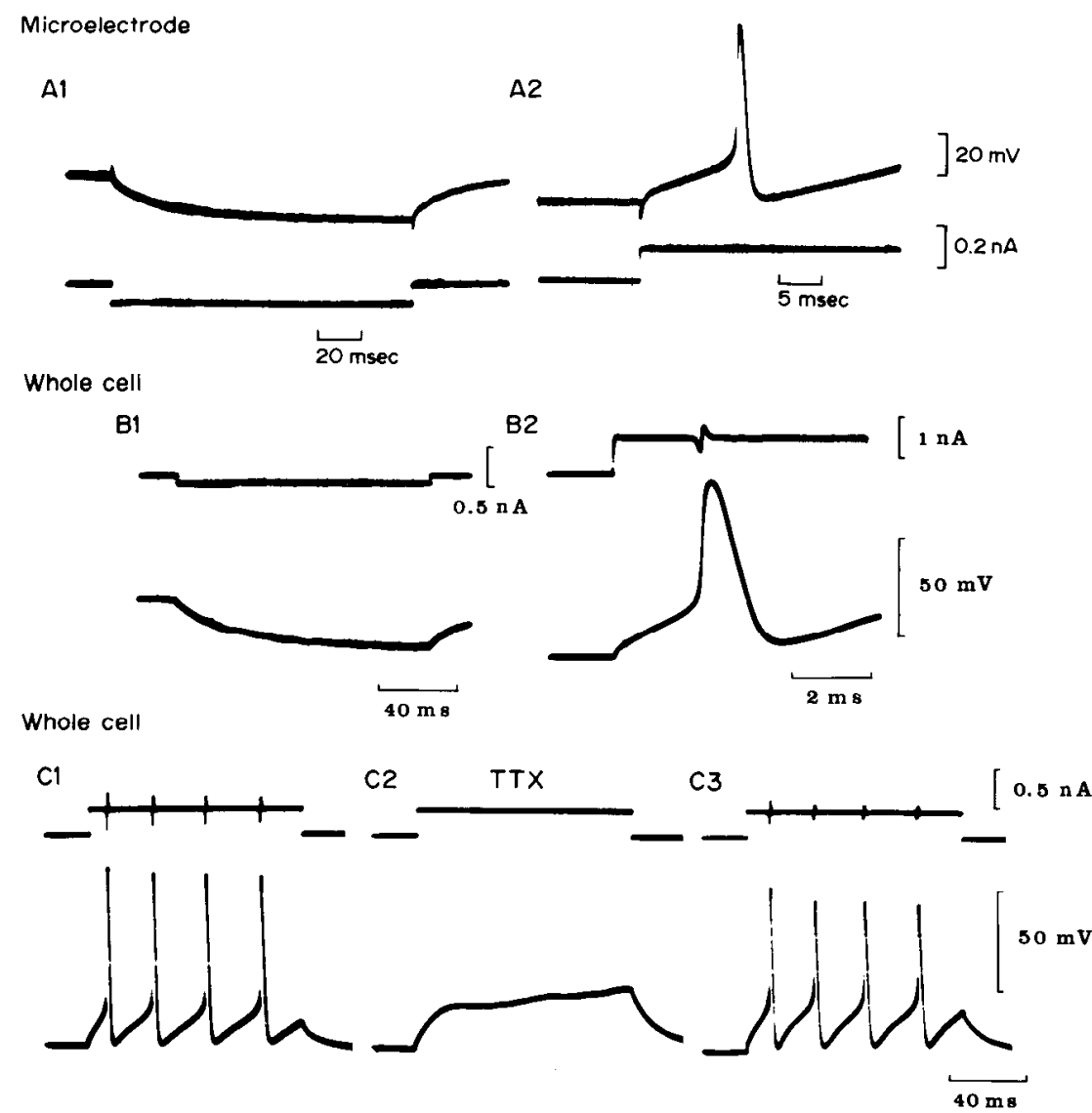

voltage produced by square step currents. Deviation from a single exponential at the initial phase, which probably represents the current flow to neuronal processes (Rall, 1969), was negligibly small. A rough estimate of the normalized electrotonic length of the dendrite cylinder (Rall, 1969) was 0.8, indicating that the cells were electronically compact.

The values of input resistance $(200-300 \mathrm{M} \Omega$ ) are larger than those obtained for the locus ceruleus neurons in vivo or in brain slice preparations: $58 \mathrm{M} \Omega$, guinea pig (Henderson et al., 1982); $25 \mathrm{M} \Omega$, rat (Aghajanian et al., 1983). This discrepancy may indicate the possibility that our cultured cells are smaller than cells in intact animals, or it could be caused by differences in the experimental temperatures $\left(32\right.$ vs $\left.37^{\circ} \mathrm{C}\right)$.

\section{Action potentials}

Action potentials were elicited by constant depolarizing currents as shown in Figure 8. The action potential was larger with the patch-clamp method than with microelectrodes $(103$ vs $71 \mathrm{mV}$; Table 3). The frequency response of the microelectrode system was lower than that of the patch-clamp system, but this cannot account for this discrepancy. (The frequency response of our typical microelectrode-amplifier system was about $3 \mathrm{kHz}$. By analyzing the action potentials recorded by the whole-cell clamp, we found that $3 \mathrm{kHz}$ was sufficient to measure the amplitude of the action potential accurately.)

When TTX, $1 \mu \mathrm{M}$, was applied by ejection or superfusion,

\begin{tabular}{|c|c|c|c|c|c|c|}
\hline $\begin{array}{l}\text { Recording } \\
\text { technique }\end{array}$ & $\begin{array}{l}\text { Resting } \\
\text { potential } \\
(\mathrm{mV})\end{array}$ & $\begin{array}{l}\text { Input } \\
\text { resistance } \\
(\mathrm{M} \Omega) \\
\end{array}$ & $\begin{array}{l}C_{\text {in }} \\
(\mathrm{pF})\end{array}$ & $\begin{array}{l}\text { AP } \\
\text { amplitude } \\
(\mathrm{mV})\end{array}$ & $\begin{array}{l}\text { AP } \\
\text { duration } \\
\text { (msec) }\end{array}$ & $\begin{array}{l}\text { Soma } \\
\text { diameter } \\
(\mu \mathrm{m})\end{array}$ \\
\hline $\begin{array}{r}\text { Microelectrode } \\
\text { data }(n=28)\end{array}$ & $-65 \pm 2$ & $315 \pm 41$ & $79 \pm 9$ & $71 \pm 2$ & $2.2 \pm 0.1$ & $(27 \pm 1)^{a}$ \\
\hline $\begin{array}{l}\text { Patch-clamp } \\
\quad \text { data }(n=7)\end{array}$ & $-77 \pm 5$ & $211 \pm 22$ & $118 \pm 15$ & $103 \pm 7$ & $2.0 \pm 0.4$ & $29 \pm 2$ \\
\hline
\end{tabular}

Data are means \pm SEM. Cells were obtained from 1 - to 4 -d-old mouse brains and cultured for 10-18 d. $C_{\text {in }}$ input capacity of the cell. AP, action potential. Only the data for cells with action potential amplitude of $\geq 60 \mathrm{mV}$ are included. Resting potential of the cells with spontaneous firing was defined as the potential during the interspike period, when it stays at a relatively constant level. The action potential duration was measured at the threshold. Soma diameter was defined as a geometrical mean, $(M m)^{1 / 2}$, of the major $(M)$ and minor $(m)$ soma diameters.

${ }^{a}$ In 4 cells the diameter was not measured; the data are based on the other 24 cells. With the patch-clamp technique, the patch pipette contained $110 \mathrm{~mm} \mathrm{~K}$-aspartate, $40 \mathrm{~mm} \mathrm{NaCl}$, etc. (see Materials and Methods); the high sodium concentration (40 mM) conforms with the intracellular fluid composition of mammalian neurons (Krnjević, 1955). 
A

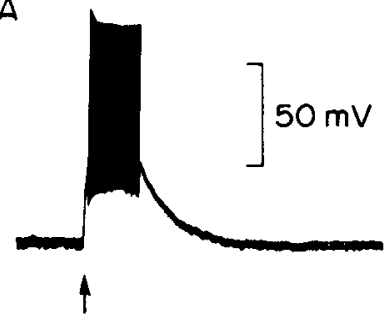

B

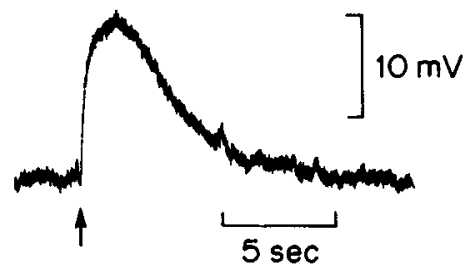

Figure 9. Voltage responses to L-glutamate applications in neurons of the locus ceruleus from (4-d-old) mice cultured for $14 \mathrm{~d}$. $A$, L-Glutamate $(10 \mu \mathrm{M})$ was applied by pressure ejection (arrow) lasting for $1.6 \mathrm{sec}$. A train of action potentials was elicited by the glutamate-induced depolarization. $B$, Another cell, superfused with a Krebs solution containing TTX $(1 \mu \mathrm{M})$. L-Glutamate was applied as in $A$. In both cells, the wholecell current clamp was used. Resting potential in $A$ was $-97 \mathrm{mV}$; in $B$, $-69 \mathrm{mV}$. The tape recorder and pen recorder combination was used, with a frequency response of $1300 \mathrm{~Hz}(A), 650 \mathrm{~Hz}(B)$.

action potentials, recorded from either rat or mice neurons, were abolished. Thus, the spike potentials are primarily caused by TTX-sensitive sodium channels, in contrast to results from brain slices (Williams et al., 1984). However, the experiment does not eliminate the possibility that there are calcium channels in these neurons that would be manifested under different conditions.

\section{Amino acid application}

The effects of L-glutamate, GABA, and glycine were investigated. Intracellular microelectrodes (K-methylsulfate filled) were generally used. As shown in Figure 9, I-glutamic acid $(10 \mu \mathrm{M})$ application produced a quick depolarization, which triggered trains of action potentials. This glutamate effect was quite consistent, and all 6 cells tested produced depolarizations.

GABA, $0.25-0.5 \mathrm{~mm}$, produced hyperpolarization ( 9 of 11 cells; microelectrode studies; Fig. 10), and this effect was suppressed by picrotoxin, $10^{-4} \mathrm{M}$ (Fig. $10 \mathrm{C}$ ), but not by strychnine, $10^{-5}$ M (Fig. 10B). Rarely (2 of 11 cells), GABA produced a small depolarization. Glycine, $0.25-0.5 \mathrm{~mm}$, was tested on 18 cells (microelectrode studies). The majority of the cells (12) responded with hyperpolarization, whereas 6 cells responded with depolarization. These responses (both hyperpolarization and depolarization) were antagonized by strychine, $10^{-5} \mathrm{M}$, but not by picrotoxin, $10^{-4} \mathrm{M}$ (Fig. $10, B, C$ ). Both GABA and glycine hyperpolarization reversed in sign at about -51 to -67 $\mathrm{mV}$. The GABA- and glycine-induced depolarizations reversed upon depolarization; the reversal point ranged from -48 to -58 $\mathrm{mV}$.

\section{Substance $P$}

Of several neuropeptides we investigated, we examined the effects of substance $P$ most extensively. All experiments were performed using the intracellular microelectrode. Of 17 cells tested with substance $\mathrm{P}, 3 \mu \mathrm{M}, 5$ cells responded with depolarization, 4 with hyperpolarization, and 8 did not produce a noticeable response. Figure $11 A I$ illustrates an example of depolarization produced by substance $\mathrm{P}$.

Figure $11 A 2$ shows the input resistance as continuously monitored by injecting recurring hyperpolarizing currents. The resistance increased by about $30 \%$ during the substance P-induced depolarization. In 1 cell, we determined the reversal potential of substance $P$ response. When the cell was hyperpolarized to $-103 \mathrm{mV}$, the substance $P$-induced response reversed its sign and became a hyperpolarizing response. The reversal potential of the response in this cell was roughly $-95 \mathrm{mV}$.

Figure $11 B$ illustrates a cell that responded with a hyperpolarization to substance $\mathbf{P}$ application even at the resting potential. The spontaneous spike potentials were inhibited during the hyperpolarization.

\section{Other neuropeptides}

Somatostatin, $1 \mu \mathrm{M}$, was applied to 3 cells, 2 of which responded with hyperpolarization (Fig. 12A) and 1 with a depolarization. $\beta$-Endorphin, $1 \mu \mathrm{M}$, was applied to 7 cells. Of these, 4 cells responded with hyperpolarization (Fig. 12B), 1 with a depolarization, and 2 gave no response. D-Ala ${ }^{2}-\mathrm{D}-\mathrm{Leu}^{5}$-enkephalin (DADLE), $1 \mu \mathrm{M}$, did not produce noticeable effects. However, al high concentrations (10-30 $\mu \mathrm{M})$ it sometimes produced hyper-
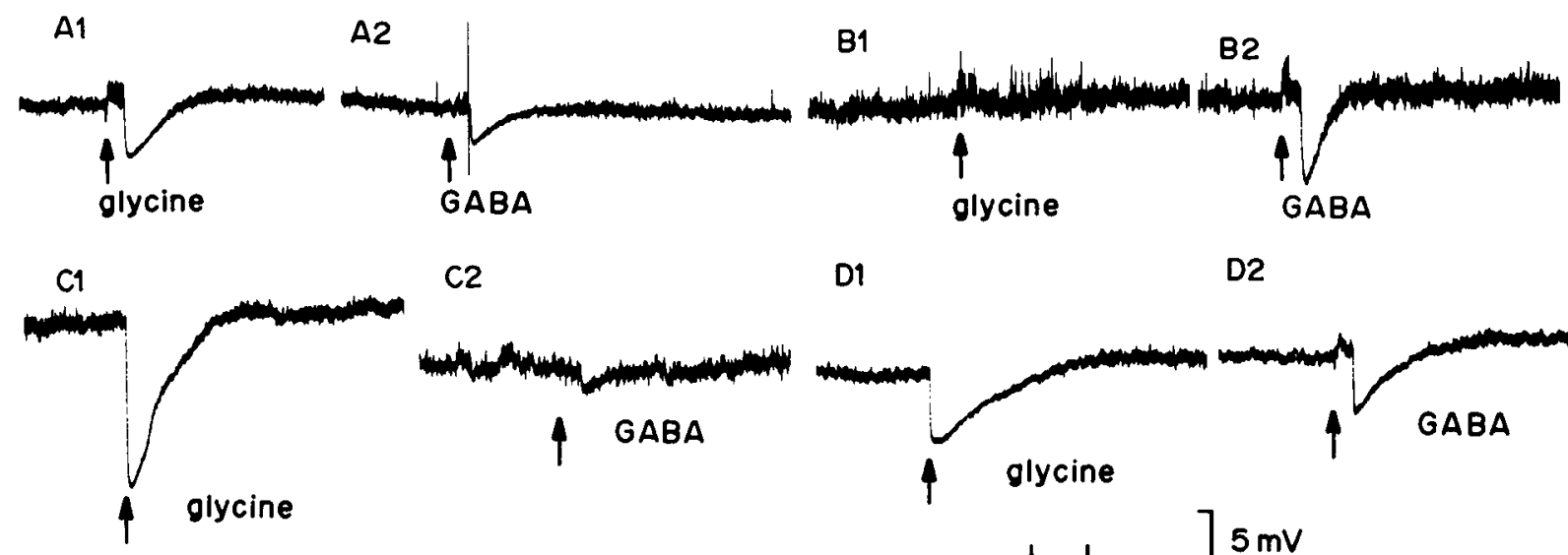

$\mathrm{C} 2$

D1

D2

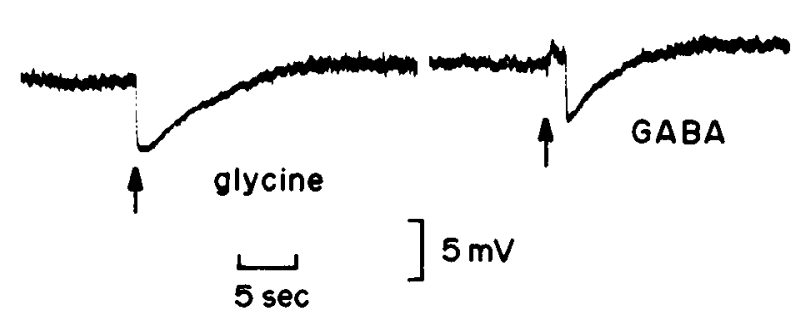

Figure 10. Application of glycine $(0.5 \mathrm{~mm})$ or GABA $(0.5 \mathrm{~mm})$ by pressure ejection to a cultured neuron from a 2-d-old mouse. Culture duration, $10 \mathrm{~d}$. Each pressure ejection started at the time indicated by an arrow and lasted for $1.6 \mathrm{sec}$. In some records, the drug ejection caused a sudden voltage change, which was probably a movement artifact. $A l$ and $A 2$, Records in a normal Krebs solution. Both glycine and GABA applications produced transient hyperpolarizations. $B I$ and $B 2$, Superfused with a Krebs solution containing $10 \mu \mathrm{M}$ strychnine. The glycine response disappeared, but the GABA response persisted. $C I$ and $C 2$, Bathing solution contained $0.1 \mathrm{~mm}$ picrotoxin. The glycine response reappeared, but the GABA response was suppressed. $D 1$ and $D 2$, Again, the chamber was superfused with normal Krebs solution. Both glycine and GABA responses were restored. The initial resting potential of the cells was $-54 \mathrm{mV}$. During the recording of the drug responses, the membrane potential was kept between -42 and $-48 \mathrm{mV}$ by either de- or hyperpolarizing currents. The tape recorder and pen recorder combination was used, with an overall frequency response of $320 \mathrm{~Hz}$. An intracellular microelectrode was used. 
A1

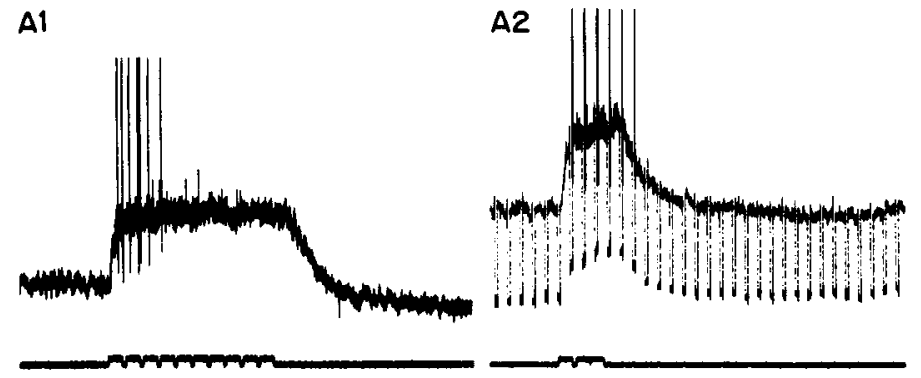

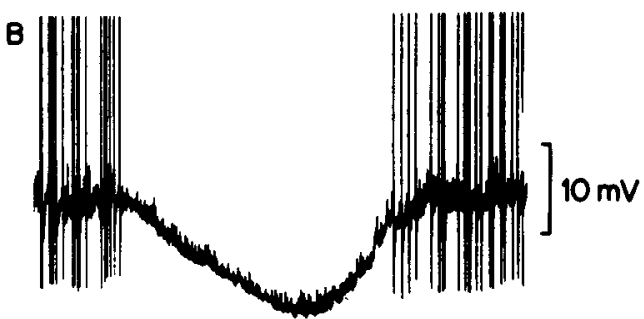

\section{0 sec}

Figure 11. Effects of substance $\mathrm{P}(3 \mu \mathrm{M})$ ejections on neurons from 2-3-d-old mice cultured for $17 \mathrm{~d}(A)$ and $18 \mathrm{~d}(B)$. Upper channels, Potential changes; lower channels, opening of the drug ejection valve. $A 1$ and $A 2$, In this cell, substance $\mathrm{P}$ produced depolarizations. In $A 2$, changes of input resistance were measured by sending constant-current pulses $(0.17 \mathrm{nA})$. During the substance $P$ depolarization, the input resistance was increased. Resting potentials were -60 to $-64 \mathrm{mV}$. $B$, In this cell, substance $\mathrm{P}$ produced a hyperpolarization. The resting potential was $-48 \mathrm{mV}$. The tape recorder and pen recorder combination was used, with an overall frequency response of $200-320 \mathrm{~Hz}$. Intracellular microelectrodes were used.

polarization ( 8 of 20 cells; Fig. $12 \mathrm{C}$ ), whereas it rarely produced a small depolarization ( 2 of 20 cells).

\section{Discussion}

\section{Cell culture of locus ceruleus}

The main aim of this paper was to describe our culture methods and to explain the characteristic features of the cell culture from the locus ceruleus. Our culture contains a high percentage $(69 \%)$ of neural cells exhibiting catecholamine histofluorescence. These cells showed other characteristics of noradrenergic neurons, such as the presence of many varicosities in the neurites (Figs. $2 C$; $4, B, C)$ and the presence of small granular vesicles under the EM in $\mathrm{KMnO}_{4}$-fixed materials (Fig. 5, $B, C$ ). The neurons are viable more than 3 weeks on the feeder layer and are amenable to the microelectrode and patch-clamp experiments. The neurons produce many physiological and pharmacological responses similar to those of locus ccrulcus ncurons in more physiological conditions. We conclude that we have obtained dissociated cell cultures of noradrenergic neurons derived from the locus ceruleus.

\section{Electrophysiology}

One of the distinct features of our cultured neurons is the presence of spontaneous, nonadapting repetitive firing of action potentials. The presence of spontaneous firing of locus ceruleus neurons has been observed in the in situ brain and in brain slice preparations (Aghajanian and VanderMaelen, 1982; Chu and Bloom, 1973; Foote et al., 1983; Williams et al., 1984). In the present study, we observed spontaneous firing in many cells which appeared to be isolated from other neurons, and also in a few isolated cells which had been cultured for only 1 day, without extensive processes; therefore, these neurons seem to be endowed with the capability of being the originators of spontaneous firing. Thus, it is very likely that locus ceruleus neurons in situ, with their innate capability of producing spontaneous firing, produce action potentials continuously, the frequency being finely tuned through the summation of depolarizing or hyperpolarizing influences from various transmitters or modifiers impinging upon them. In other words, locus ceruleus neurons themselves are probably the pacemakers for the continuous firing. This nonadapting firing of noradrenergic neurons is in sharp contrast to the behavior of cholinergic neurons derived from the basal forebrain nuclei (the nucleus basalis of Meynert, etc.). We have recently shown that cultured neurons from these cholinergic nuclei do not produce long-lasting repetitive firing (Nakajima et al., 1985).
We observed that the neurons occasionally produced a bursting behavior, high-frequency trains of spikes alternating with silent periods. Such bursting behavior of locus ceruleus neurons has been reported in the in vivo brain (Chu and Bloom, 1974). Aghajanian et al. (1983) and Williams et al. (1984) presented evidence indicating that $\mathrm{Ca}$-dependent $\mathrm{K}$ channels are involved in producing the quiescent period. Our present experiments were not planned to elucidate the mechanism of the bursting behavior itself. We only wish to emphasize the fact that the bursting behavior occurs in cultured, isolated neurons apparently without neighboring neurons, in agreement with the model predicted by Plant (1978) and Scriven (1981).

\section{Amino acids}

The cultured locus ceruleus neurons consistently responded to L-glutamic acid application with depolarization. This is in agreement with the observation by Henderson et al. (1982) on the brain slice preparations. According to them, glutamate has an excitatory effect on locus ceruleus neurons but hardly any effects on the mesencephalic nucleus of the trigeminal nerves, which are located in the vicinity of the locus ceruleus.

Cedarbaum and Aghajanian (1977), working on the in situ brain, observed that GABA inhibits the discharge of spontaneous spikes in locus ceruleus neurons. The present experiments, in which GABA and glycine produced a hyperpolarization in the majority of our cultured cells, indicate that the result by Cedarbaum and Aghajanian (1977) was at least partly a direct postsynaptic effect. Sometimes, however, we encountered cells that produced depolarizations by GABA and glycine. This phenomenon is probably related to the fact that GABA (or glycine) produces depolarizing responses in young embryonic spinal cord neurons (Bixby and Spitzer, 1984; Obata et al., 1978). It is possible that our cultured neurons, which were derived from newborn rats, are at a stage when there is a mixture of 2 types of cells: the embryonic depolarizing type and the adult hyperpolarizing type.

\section{Substance $P$}

There are reports about the presence on the locus ceruleus neurons of presynaptic nerve endings containing substance P-like immunoreactivity (Pickel et al., 1979). Also, the locus ceruleus is known to be rich in substance $P$ receptors (Mantyh et al., 1984; Quirion et al., 1983; Rothman et al., 1984). Previous studies using extracellular recording have shown that application of substance $P$ increases the firing rate of locus ceruleus neurons (Guyenet and Aghajanian, 1977). This is in keeping with many reports of the excitatory influences of substance $P$ 
A

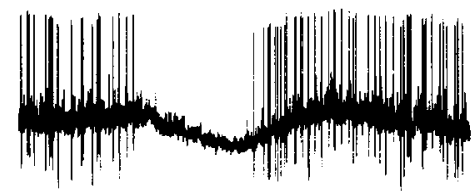

Somatostatin
B

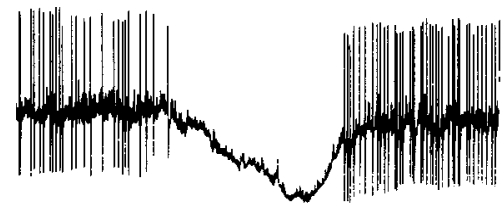

$\beta$-endorphin
C

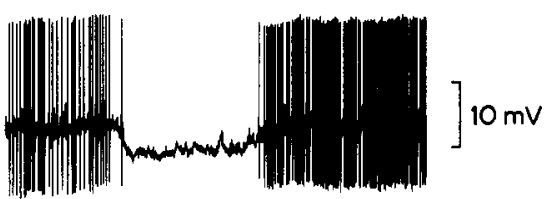

DADLE

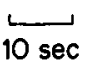

Figure 12. Effects of neuropeptides on cultured locus ceruleus neurons from 2-3-d-old mice. Culture period was $18 \mathrm{~d}(A, B)$ or $15 \mathrm{~d}(C)$. $A$, Somatostatin $(1 \mu \mathrm{M})$ was ejected. Resting potential (interspike potential) was $-38 \mathrm{mV} . B$, Effect of $\beta$-endorphin $(1 \mu \mathrm{M})$ ejection. Resting potential was $-46 \mathrm{mV}$. C , Effect of $\mathrm{D}-\mathrm{Ala}^{2}-\mathrm{D}-\mathrm{Leu}^{5}$-enkephalin (DADLE) $(30 \mu \mathrm{M})$ ejection. Resting potential was $-50 \mathrm{mV}$. The tape recorder and pen recorder combination was used, with a frequency response of $200 \mathrm{~Hz}$. Intracellular microelectrodes were used.

on various parts of the nervous system (Nicoll et al., 1980; Otsuka and Takahashi, 1977). In agreement with these observations, we found that substance $P$ produced depolarizations in a substantial percentage of cultured neurons, indicating a direct postsynaptic action of substance $P$.

During the depolarization, we observed an increase in membrane resistance, in keeping with the idea that substance $P$ produces depolarization by decreasing potassium permeability (Adams et al., 1983; Akasu et al., 1983; Katayama et al., 1979; Nowak and Macdonald, 1981). Our observation that there was a reversal potential in the substance $\mathrm{P}$-induced response around $-95 \mathrm{mV}$ indicates that the channels on which substance $P$ exerts its effects operate over a potential region more hyperpolarized than the resting potential. Indeed, recent results from our laboratory on cultured cholinergic neurons from the nucleus basalis of Meynert in the rat basal forebrain have shown that substance $P$ produces depolarization by decreasing the $\mathrm{K}$-permeability associated with inward rectification channels (Stanfield et al., 1985).

In some cells we observed a substance P-induced hyperpolarization. This is difficult to explain. It could be an aberrant effect caused by culturing.

\section{Other neuropeptides}

Our experiments on the effects of neuropeptides are not extensive. But we want to point out that both somatostatin and $\beta$-endorphin produced a substantial hyperpolarization in these neurons, and our system will be useful in investigating the ionic mechanisms of these peptide effects.

\section{Characteristics of our culture.}

Our method of culture appears to be similar to that described by Yamamoto et al. (1981) for serotonergic neurons, and we owe the development of our technique to this work. Nevertheless, it seems pertinent to point out the differences between their method and ours.

Yamamoto et al. (1981) used embryonic rat brains, whereas we used newborn rat brains. In Yamamoto et al.'s study, quite large areas of the brain stem, which contains serotonin cells, were cut out first and then sectioned with a tissue chopper; sections were then dissociated and cultured in $35 \mathrm{~mm}$ dishes. After 1-2 weeks in culture, $7 \%$ of the neural population was found to be 5 -HT neurons. After 4 weeks, the relative population of the 5-HT neurons increased to $36 \%$, because other types of neurons disappeared. In the present work, we first made Vibratome sections of the brain stem, and the locus ceruleus was dissected out under direct visualization. The total number of our cells was small, and the cells were cultured in a very small $(1.2 \mathrm{~cm}$ diameter) well. About $70 \%$ of the neurons were noradrenergic after 2 weeks of culture. We did not make a systematic survey of the survival rate, because our primary purpose was to make a culture system usable for electrophysiology rather than for observation of the dynamic behavior of the cells in culture conditions.

Buse and Matthaei (1983) described a technique of culturing a particular nucleus of the brain by locating it using stereotaxic coordinates. But our method, in which the location of neurons was identified visually, is much simpler. Also, there have been reports that certain types of neurons in the CNS were cultured with high purity either by dissociating the neurons just after the completion of their mitosis but before the mitosis of neighboring neurons (Masuko et al., 1979) or by using the cell sorter for neurons labeled by fluorescein conjugates (O'Brien and Fischbach, 1983). The applicability of these techniques seems to be limited to certain types of neurons.

Our method probably can be applied to almost any nucleus of the brain, even if it is located deep inside the brain. A fairly pure culture will be obtained if the neurons are grouped together. Thus, our method has the potential to become an important tool for investigating many types of ncurons in the CNS. Wc have recently succeeded in obtaining a dissociated culture of cholinergic neurons from the nucleus basalis by using the same technique (Nakajima et al., 1985). The cell culture of relatively homogeneous neuronal types will greatly aid in understanding the biochemical and physiological properties of various kinds of neurons in the CNS. One of the advantages of cell culture is the possibility of exploring the mechanisms of ionic channels by use of the patch-clamp technique (Hamill et al., 1981), which promises to elucidate the molecular behavior of these channels.

\section{References}

Adams, P. R., D. A. Brown, and S. W. Jones (1983) Substance P inhibits the M-current in bullfrog sympathetic neurones. Br. J. Pharmacol. 79: 330-333.

Aghajanian, G. K., and C. P. VanderMaelen (1982) Intracellular identification of central noradrenergic and serotonergic neurons by a new double labeling procedure. J. Neurosci. 2: 1786-1792.

Aghajanian, G. K., C. P. VanderMaelen, and R. Andrade (1983) Intracellular studies on the role of calcium in regulating the activity and reactivity of locus coeruleus neurons in vivo. Brain Res. 273: 237243.

Akasu, T., T. Nishimura, and K. Koketsu (1983) Substance P inhibits the action potentials in bullfrog sympathetic ganglion cells. Neurosci. Lett. 41: 161-166.

Amaral, D. G., and H. M. Sinnamon (1977) The locus coeruleus: Neurobiology of a central noradrenergic nucleus. Prog. Neurobiol. 9: 147-196.

Andén, N.-E., A. Dahlström, K. Fuxe, K. Larsson, L. Olson, and U. Ungerstedt (1966) Ascending monoamine neurons to the telencephalon and diencephalon. Acta Physiol. Scand. 67: 313-326. 
Bixby, J. L., and N. C. Spitzer (1984) The appearance and development of neurotransmitter sensitivity in Xenopus embryonic spinal neurones in vitro. J. Physiol. (Lond.) 353: 143-155.

Bridgman, P. C., S. Nakajima, A. S. Greenberg, and Y. Nakajima (1984) Freeze-fracture and electrophysiological studies of newly developed acetylcholine receptors in Xenopus embryonic muscle cells. J. Cell Biol. 98: 2160-2173.

Buse, E., and H. Matthaei (1983) A method for defined sectioning of fresh young brains and collection of small regions for cell and tissue culture. J. Neurosci. Methods 7: 377-387.

Cedarbaum, J. M., and G. K. Aghajanian (1977) Catecholamine receptors on locus coeruleus neurons: Pharmacological characterization. Eur. J. Pharmacol. 44: 375-385.

Choi, D. W., and G. D. Fischbach (1981) GABA conductance of chick spinal cord and dorsal root ganglion neurons in cell culture. J. Neurophysiol. 45: 605-620.

Chu, N.-S., and F. E. Bloom (1973) Norepinephrine-containing neurons: Changes in spontaneous discharge patterns during sleeping and waking. Science 179: 908-910.

Chu, N.-S., and F. E. Bloom (1974) Activity patterns of catecholaminecontaining pontine neurons in the dorso-lateral tegmentum of unrestrained cats. J. Neurobiol. 5: 527-544.

Dahlström, A., and K. Fuxe (1964) Evidence for the existence of monoamine-containing neurons in the central nervous system. I. Demonstration of monoamines in the cell bodies of brain stem neurons. Acta Physiol. Scand. [Suppl. 232] 62: 1-55.

Dreyfus, C. F., M. D. Gershon, and S. M. Crain (1979) Innervation of hippocampal explants by central catecholaminergic neurons in cocultured fetal mouse brain stem explants. Brain Res. 161: 431-445.

Dreyfus, C. F., K. A. Markey, M. Goldstein, and I. B. Black (1983) Development of catecholaminergic phenotypic characters in the mouse locus coeruleus in vivo and in culture. Dev. Biol. 97: 48-58.

Foote, S. L., F. E. Bloom, and G. Aston-Jones (1983) Nucleus locus coeruleus: New evidence of anatomical and physiological specificity. Phys. Rev. 63: 844-914.

Guyenet, P. G., and G. K. Aghajanian (1977) Excitation of neurons in the nucleus locus coeruleus by substance $P$ and related peptides. Brain Res. 136: 178-184.

Hamill, O. P., A. Marty, E. Neher, B. Sakmann, and F. J. Sigworth (1981) Improved patch-clamp techniques for high-resolution current recording from cells and cell-free membrane patches. Pfluegers Arch. 391: 85-100.

Hendclman, W. J., K. C. Marshall, R. Ferguson, and S. Carrière (1982) Catecholamine neurons of the central nervous system in organotypic culture. Dev. Neurosci. 5: 64-76.

Henderson, G., C. M. Pepper, and S. A. Shefner (1982) Electrophysiological properties of neurones contained in the locus coeruleus and mesencephalic nucleus of the trigeminal nerve in vitro. Exp. Brain Res. 45: 29-37.

Hökfelt, T. (1967) On the ultrastructural localization of noradrenaline in the central nervous system of the rat. Z. Zellforsch. 79: 110-117.

Katayama, Y., R. A. North, and J. T. Williams (1979) The action of substance $\mathrm{P}$ on neurons of the mysenteric plexus of the guinea-pig small intestine. Proc. R. Soc. Lond. [Biol.] 206: 191-208.

Krnjević, K. (1955) The distribution of $\mathrm{Na}$ and $\mathrm{K}$ in cat nerves. J. Physiol. (Lond.) 128: 473-488.

Lauder, J. M., and F. E. Bloom (1975) Ontogeny of monoamine neurons in the locus coeruleus, raphe nuclei and substantia nigra of the rat. II. Synaptogenesis. J. Comp. Neurol. 163: 251-264.

Léger, L., and M.-L. Hernandez-Nicaise (1980) The cat locus coeruleus. Anat. Embryol. 159: 181-198.

Mantyh, P. W., S. P. Hunt, and J. E. Maggio (1984) Substance P receptors: Localization by light microscopic autoradiography in rat brain using $\left({ }^{3} \mathrm{H}\right) \mathrm{SP}$ as the radioligand. Brain Res. 307: 147-165.

Masuko, S., H. Kuromi, and Y. Shimada (1979) Isolation and culture of motoneurons from embryonic chicken spinal cords. Proc. Natl. Acad. Sci. USA 76: 3537-3541.

Masuko, S., Y. Nakajima, and S. Nakajima (1984) Noradrenergic. neurons from the nucleus locus coeruleus in dissociated cell cultures: Culture methods, morphology and electrophysiology. Soc. Neurosci. $\Lambda$ bstr. 10: 659 .

Nakajima, Y., S. Nakajima, K. Obata, C. G. Carlson, and K. Yamaguchi (1985) Dissociated cell culture of cholinergic neurons from nucleus basalis of Meynert and other basal forebrain nuclei. Proc. Natl. Acad. Sci. USA 82: 6325-6329.
Nakamura, S., and K. Iwama (1975) Antidromic activation of the rat locus coeruleus neurons from hippocampus, cerebral and cerebellar cortices. Brain Res. 99: 372-376.

Nicoll, K. A., C. Schenker, and S. E. Leeman (1980) Substance P as a transmitter candidate. Annu. Rev. Neurosci. 3: 227-268.

Nowak, L. M., and R. L. Macdonald (1981) Substance P decreases a potassium conductance of spinal cord neurons in cell culture. Brain Res. 214: 416-423.

Obata, K., M. Oide, and H. Tanaka (1978) Excitatory and inhibitory actions of GABA and glycine on embryonic chick spinal neurons in culture. Brain Res. 144: 179-184.

O'Brien, R. J., and G. D. Fischbach (1983) Modulation of motoneuron glutamate sensitivity by interneurons in vitro. Soc. Neurosci. Abstr. 9: 1178.

O'Lague, P. H., D. D. Potter, and E. J. Furshpan (1978) Studies on rat sympathetic neurons developing in cell culture. I. Growth characteristics and electrophysiological properties. Dev. Biol. 67: 384403.

Olpe, H. R., and R. S. G. Jones (1982) Excitatory effects of ACTH on noradrenergic neurons of the locus coeruleus in the rat. Brain Res. 251: 177-179.

Olson, L., and K. Fuxe (1971) On the projections from the locus coeruleus noradrenaline neurons: The cerebellar innervation. Brain Res. 28: 165-171.

Olson, L., T. Ebendal, and A. Seiger (1979) NGF and anti-NGF: Evidence against effects of fiber growth in locus coeruleus from cultures of perinatal CNS tissues. Dev. Neurosci. 2: 160-176.

Otsuka, M., and T. Takahashi (1977) Putative peptide neurotransmitters. Annu. Rev. Pharmacol. Toxicul. 17: 425-439.

Pickel, V. M., T. H. Joh, D. J. Reis, S. E. Leeman, and R. J. Miller (1979) Electron microscopic localization of substance P and enkephalin in axon terminals related to dendrites of catecholaminergic neurons. Brain Res. 160: 387-400.

Plant, R. E. (1978) The effects of calcium ${ }^{++}$on bursting neurons. A modeling study. Biophys. J. 21: 217-237.

Prochiantz, A., U. Di Porzio, A. Kato, B. Berger, and J. Glowinski (1979) In vitro maturation of mesencephalic dopaminergic neurons from mouse embryos is enhanced in presence of their striatal target cells. Proc. Natl. Acad. Sci. USA 76: 5387-5391.

Quirion, R., C. W. Shults, T. W. Moody, C. B. Pert, T. N. Chase, and T. L. O'Donohue (1983) Autoradiographic distribution of substance $P$ receptors in rat central nervous system. Nature 303: 714-716.

Rall, W. (1969) Time constants and electrotonic length of membrane cylinders and neurons. Biophys. J. 9: 1483-1508.

Rothman, R. B., M. Herkenham, C. B. Pert, T. Liang, and M. A. Cascieri (1984) Visualization of rat brain receptors for the neuropeptide, substance P. Brain Res. 309: 47-54.

Schlumpf, M., W. J. Shoemaker, and F. E. Bloom (1977) Explant cultures of catecholamine-containing neurons from rat brain: Biochemical, histofluorescence, and electron microscopic studies. Proc. Natl. Acad. Sci. USA 74: 4471-4475.

Scriven, D. R. L. (1981) Modeling repetitive firing and bursting in a small unmyelinated nerve fiber. Biophys. J. 35: 715-730.

Sievers, J., and I. Lolova (1981) Morphological studies on the development of the rat locus coeruleus. Bibl. Anat. 19: 192-197.

Stanfield, P. R., Y. Nakajima, and K. Yamaguchi (1985) Substance P raises neuronal membrane excitability by reducing inward rectification. Nature 315: 498-501.

Svensson, T. H., B. S. Bunney, and G. K. Aghajanian (1975) Inhibition of both noradrenergic and serotonergic neurons in brain by the $\alpha$-adrenergic agonist clonidine. Brain Res. 92: 291-306.

Swanson, L. W. (1976) The locus coeruleus: A cytoarchitectonic, Golgi and immunohistochemical study in the albino rat. Brain Res. 110 . 39-56.

Swanson, L. W., and B. K. Hartman (1975) The central adrenergic system. An immunofluorescence study of the location of cell bodies and their efferent connections in the rat utilizing dopamine-B-hydroxylase as a marker. J. Comp. Neurol. 163: 467-506.

Takahashi, T. (1978) Intracellular recording from visually identified motoneurons in rat spinal cord slices. Proc. R. Soc. Lond. [Biol.] 202. $417-421$.

Ungerstedt, U. (1971) Stereotaxic mapping of the monoamine pathways in the rat brain. Acta Physiol. Scand. [Suppl.] 367: 1-48.

Victorov, I., J. Nguyen-Legros, J.-M. Boutry, M. Gay, B. Berger, and J.-J. Hauw (1978) Culture des tissus: Technique simple de culture 
du noyau de locus cocrulus du Souriceau nouveau-né. C. R. Acad. Sci. (Paris) 286: 1893-1895.

Williams, J. T., T. M. Egan, and R. A. North (1982) Enkephalin opens potassium channels on mammalian central neurons. Nature 299: 7477

Williams, J. T., R. A. North, S. A. Shefner, S. Nishi, and T. M. Egan
(1984) Membrane properties of rat locus coeruleus neurones. Neuroscience 13: 137-156.

Yamamoto, M., H. W. M. Steinbusch, and T. J. Jessell (1981) Differentiated properties of identified serotonin neurons in dissociated cultures of embryonic rat brain stem. J. Cell Biol. 91: 142-152. 